\title{
Ficción, sexualidad y raza en The Dumb Virgin y The Unfortunate Bride de Aphra Behn
}

\author{
(Fancy, Gender and Race in Aphra Behn's \\ The Dumb Virgin and The Unfortunate Bride)
}

\author{
YAO-HSI JOSÉ SHIH \\ donjose@mail.stust.edu.tw \\ Southern Taiwan University of Science and Technology
}

Fecha de recepción: 28 de agosto de 2014

Fecha de aceptación: 1 de noviembre de 2014

Resumen: Trabajo que pretende estudiar la representación física de los personajes Belvideera, María y Celesia en las obras de Aphra Behn "The Dumb Virgin: Or the Force of Imagination" y "The Unfortunate Bride: Or the Blind Lady a Beauty". Tiene como objetivo interpretar la importancia de los defectos físicos de las jóvenes heroínas basándose en Characteristics of Men, Manners, Opinions, Times de Shaftesbury. El artículo relata en primer lugar la ficción de las historias feminocéntricas de Behn en relación con los tratados de moral de Shaftesbury, que dividen y malinterpretan la imaginación maternal como algo defectuoso y monstruoso. Posteriormente, argumenta que la autora da mayor relevancia al tema de la misoginia, dotando a sus jóvenes protagonistas femeninas con una doble deformación, en la que la maternidad imperfecta da a luz a una segunda generación de hijos imperfectos, mientras la feminidad deformada en los mismos sucesos de defectos se entremezcla con las implicaciones exóticas y raciales de la degeneración y el mestizaje. Las historias de amor de la autora, amparadas en el sexo y la raza, son trágicas, mientras que las de Shaftesbury sobre sexualidad y raza emanan del vicio de la monstruosidad y están diseñadas para la perpetración de actos monstruosos. Mediante la dotación de características monstruosas femeninas y raciales, como se explica en el siguiente trabajo, Behn crea una historia para inventar un narrador como resolución dialéctica a la construcción binaria de oposiciones de Shaftesbury en su instrucción moral. Aunque la narradora de Behn cede su poder autoría y se presenta como una mera relatadora de historias, su pluma femenina ejerce su autoridad haciendo justicia a sus personajes y sus fantasías literarias, reconociendo así a la escritora femenina como una artista, una creadora de ficción. Desde el punto de vista de la trascendencia dialéctica, la narradora de las ficciones románticas no solo evita la jerarquía 
socio-sexual y la dicotomía entre sexualidad y raza, sino que también señala de forma tácita un avance en el dominio discursivo patriarcal generalizado.

Palabras clave: Aphra Behn, Shaftesbury, ficción, sexualidad, raza.

Abstract: This paper studies the representation of physically defective characters, Belvideera, Maria, and Celesia in Aphra Behn's novellas: "The Dumb Virgin: Or, the Force of Imagination," and "The Unfortunate Bride: Or, the Blind Lady a Beauty." It aims to interpret the significance of the young heroines' physical disabilities in the context of Shaftesbury's Characteristics of Men, Manners, Opinions, Times. The essay first relates fancy in Behn's feminocentric stories to that in Shaftesbury's moral treatise, which biases and misconstrues the maternal imagination as defective and monstrous. It then argues that Behn, expanding this misogynist motif, constructs her young female protagonists as doubly deformed, as flawed motherhood gives birth to a second generation of flawed daughterhood, while the deformed femininity in the twin tales of defect is invariably intertwined with the exotic, racial implications of miscegenation and degeneration. Sexualized and racialized, Behn's tales of love are tragic, in which Shaftesbury's antithetical Others of gender and race are constructed upon the vice of monstrousness and aligned to commit monstrous acts. By monstrocizing female and racial others, as this paper proposes, Behn makes out a case for deploying a narrator as dialectical resolution to Shaftesbury's binary construct of oppositions in his moral instruction. Although Behn's female narrator gives in her authorial power and abases herself as a mere teller of tales, her female pen exercises her authority by doing justice to her characters and her literary fancy, and thus registers the female teller as an artist, and fiction-maker. As dialectical transcendence, the female narrator in the romantic fictions not only circumvents socio-sexual hierarchy and gender-racial dichotomy, but also tacitly points to a breakthrough amid the pervasive patriarchal discursive dominance.

Key words: Aphra Behn, Shaftesbury, Fancy, Gender, Race.

\section{INTRODUCTION}

When Aphra Behn finally attracted attention and was recognized as a major woman writer in the late twentieth century, critics were first taken up with her biography. ${ }^{1}$ Heidi Hutner, perceiving the complexities of "fissures

${ }^{1}$ Angeline Goreau, Ruth Perry, Hilda Lee Smith, Jane Spenser, Elaine Hobby, and Janet Todd, among others, were committed to Behn's life in their studies. Although Janet Todd later edited Aphra Behn Studies, in which the articles cover her plays, poetry, fiction, and biography, three in 
and discontinuities" in Behn's canon, edits Rereading Aphra Behn: History, Theory, and Criticism, to "diversify the debate in Behn studies beyond the discussion of her biography... and to demonstrate how the discourses of gender, race, and class interpenetrate in her work" (6). Among the contributors to Hutner's volume, Ros Ballaster examines two of Behn's less known novellas of tragic romance: "The Dumb Virgin: Or, the Force of Imagination" and "The Unfortunate Bride: Or the Blind Lady a Beauty." Ballaster not only finds the amatory stories "a vehicle through which she [Behn] could both articulate her Tory views and still earn her bread" (9), but also notices "Behn's feminist and party politics as deeply at odd" (189). ${ }^{2}$ While Ballaster pursues her interest in the author, and focuses on the issue of female subjectivity, this essay aligns the female "subjected" with their racial counterparts, and associates this tragic alliance of gender and ethnic others with the autonomous female writer as the "subject," to come up with a breakthrough, rather than "an unresolvable contradiction" (189), as Ballaster conceives.

On the other hand, in The Limits of the Human: Fictions of Anomaly, Race, and Gender in the Long Eighteenth Century, Felicity Nussbaum also deals, though cursorily, with the same feminocentric tales, as bit part of her survey on "categories of the human" (1), in which she examines the representation of humans by intermingling gender and race with "a range of disabilities" and "physical and mental oddities" (1). Nussbaum attributes the pervasive literary, cultural and social representations of deformed womanhood, during a long period from the late seventeenth to early nineteenth century, to the misogynist beliefs in both the "immoderate desire, and her womb." ${ }^{3}$ Although Ballaster and Nussbaum both provide some food

four essays in the fiction section focus on "Oroonoko: Or the Royal Slave."

2 Ballaster, in "'Pretences of State': Aphra Behn and the Female Plot," points out "an unresolvable contradiction" between "Behn's feminist and party politics." She relates politically Behn's "female narrative voice and her devotion to the authority of the king," to the embroilment of "ideological differences of Whig and Tory" (189). As editor of Rereading Aphra Behn, Hutner also shares a similar view that Ballaster grounds the "construction of women" (9-10) upon Behn's royalism and Tory views, and ascribes this "conflicted representation of women as both subject and subjected" to "her own ambivalent position in Restoration society" (10). According to Ballaster, Behn deploys a "confusion" of victimized young female characters and autonomous female writer and makes "an attempt to solve it" (189). As point of departure, the purpose of this essay strives to stamp this "confusion" as a narratorial must. Behn, as this essay argues, not only necessitates a double representation of women in her fictions as "subject" and "subjected," but also aligns the female "subjected" with their racial counterparts. And this paper proposes that Behn strategically contrasts the alignment of gender and race with the autonomous female writer, to highlight the female writer in late seventeenth century as a solution amid the wideranging patriarchal dominance.

3 Nussbaum's notion of "anomaly" and reference to Anthony Ashley Cooper's idea of "monstrosity" are essential and instrumental in setting up this essay. She interprets the concept of deformed femininity from both idealistic and materialistic perspectives, as she traces the 
for thought and help germinate the present essay, the former's points of interest are confined within the specified radius of Behn and gender, while the latter's double-edged interpretation of deformed womanhood snatches the limelight of maternal imagination, which, as this essay argues, is the focal point.

Thus as point of departure, this essay studies the interplay of fancy, gender and race in Aphra Behn's twin fictions of defect. It first examines how Behn approaches and represents fancy, and how it is related to and defined in the Shaftesburian context. Then it argues how Behn, availing herself of this misogynist motif, constructs her young heroines as doubly deformed. Meanwhile, as two human subcategories, this paper associates gender and racial others and explores diachronically and synchronically their significance in literary and theoretical discourses. On top of this, this study highlights the simultaneous representation of woman as narrator and character in an attempt to make sense to the narrative strategy, as applied in

mother's deliveries of the two disabled heroines in "The Dumb Virgin" to both maternal "immoderate desire" and her "defective" womb:

In both cases the mother's reproductive power is compromised by immoderate desire, and her womb, the defective appendage, makes manifest her hidden faults to produce a more definitive second category of flawed femininity in the second generation. (28)

In other words, Nussbaum deems the misogynist discourse as double-edged in constructing a defective physical and mental womanhood. She refers to several sources to support her thesis on the idea of defect. However, this paper argues that, at the beginning of the first chapter, Nussbaum misinterprets the meaning of "defect" (23), in Alexander Pope's "Epistle to a Lady," as the defective female reproductive organs. In fact, in this misogynist poem, Pope's "defect" is a generic hyponym that refers to numerous parts of the female body and mind, rather than specifically zero in on their reproductive organs. For another, Nussbaum further makes her case by citing, from Female Rights Vindicated, an anonymous author's contention to confute the misogynist assumption of an inferior female body:

Each [sex] was perfect in its Way; and it was necessary they should be disposed as we see them, and every Thing that depends upon their respective constitutions; is to be consider'd as Part of their Perfection. It is therefore without Foundation, that some imagine the Women are not so perfect as the Men, and represent that as a Defect, which is an essential Appendage to their Sex, without which they could not answer the Intent of their Creation. (89)

The unnamed author challenges the misogynist belief in the defective female "Appendage," and asserts women's reproductive power as "Part of their Perfection" graced by God, which, of course, justifies Nussbaum's argument. Yet, accentuating the defective female "Appendage," in the contexts of the novellas, "The Dumb Virgin" and "The Unfortunate Bride," overshoots the target, as they are more directly concerned with the maternal imagination. In fact, as this paper points out, the maternal imagination is the coordinate point of Aphra Behn's and Anthony Ashley Cooper's discourses. In their respective narratives, they unanimously make the maternal imagination as a case in point, rather than the womb, as claimed by Nussbaum. 
Behn's novellas.

\section{SETTING THE TONE OF FANCY}

Behn, in "The Dumb Virgin" and "The Unfortunate Bride," respectively brewsand weighs the idea of fancy, though throwing it in negative lights. In "The Unfortunate Bride," Celesia, the blind heroine, who has "all other Respects charming to a wonder," except for "having been born without the use of Sight" (405), contends that "Sight is Fancy" (406), as she, defending her "Misfortune of the loss of Sight," argues "if I fancy I see him [Frankwit], sure I do see him" (406). Frankwit, the hero, not only falls in with her, but even prioritizes fancy over sight: "'This is indeed, a charming Blindness'... and the fancy of your Sight excels the certainty of ours" (406). Whether Frankwit caters for Celesia, or truly sets "fancy" above "Sight" is not the focus of attention here. But if readers follow Behn's plotline, particularly after Frankwit leaves for Cambridgeshire to settle his mortgage problem, fancy starts to take on a negative light.

It is said that in the lodging house--"a Cousin's House"--where Frankwit accommodates, there also lives "Moorea," "a Blackamoor Lady, then a Widower,"whom a certain "whimsical Knight had taken a Fancy to enjoy" (410). The starry-eyed ("whimsical") knight is said to have "taken a Fancy" to take Moorea to wife. Moorea, a racial other as her name literally reveals, is portrayed as both coloured and Moorish ("a Blackamoor Lady"): a stereotype of sexual, racial and religious other. In the story, the "Blackamoor Lady" is both racialized and sexualized, as she is discredited to be "black in her mind" (411) and "all Terms are with her unlawful" (410). Worse, she is heathenized and demonized as "Devil" (411). Unfortunaely "as if there were not hell enough in Matrimony," the foolhardy venturing knight strikes a deal with a shedevil, and immediately pays the price for his "Fancy," as he soon dies after just freshly relishing "the Devil in the Flesh" and leaves Moorea "six thousand Pounds per Ann" (410-411).

And now the shedevil sets her eyes upon Frankwit at the lodging. Stirred up by jealousy, she seizes the love letters passed to-and-fro between Frankwit and Belvira, who "only boasted Charms to move him [Frankwit]" (403), and later on, even viciously sends the false news of Frankwit's death. Here, Behn's "The Unfortunate Bride" sends out a clear message: Fancy, if not morally moderated and properly managed, could be fatal, as exemplified by the fate of the whimsical" knight, and particularly, embodied by the sexual, racial, and religious figure, Moorea. Perhaps the latter is more alarming in that fancy, if racialized, sexualized and monstrocized, as incarnated by Moorea, could trigger a monstrous series of tragedies, which eventually befall Frankwit and others.

Frankwit is partly right, as he muses metaphorically that erotic desire 
is "indeed a Monster which Enjoyment would not satisfy: I should take no pleasure... running from Hill to Hill, like Children chasing that Sun, which I could never catch" (407). In other words, Frankwit reads erotic fantasy as a paradox: it is monstrous because of its insatiable nature, but paradoxically, pursuing fancy is as futile as "chasing that Sun," which nobody can outrun. Indeed, whether in "The Dumb Virgin" or "The Unfortunate Bride," fancying is literally unquenchable. But it would be understated to simply similize the futility of it as simply chasing the sun or rainbows. Perhaps, beyond Frankwit's awareness and comprehension, the characterization of Moorea particulary models on monstrousness of a lethal kind, as the evil machination out of her monstrous fancy can single-handedly wreak havoc on the lives of her husband, Frankwit, and subsequently, other people.

In analogy, Senator Rinaldo's wife, Moorea's white counterpart, is also made an Aunt Sally in "The Dumb Virgin." But rather than linger over the erotic aspect of fancy as in "The Unfortunate Bride," in "The Dumb Virgin," the power of imagination holds the limelight. In fact, the story is plainly presented and directly associated with the disabilities of the heroines, as it is saliently laid out by the title and subtitle of the short novel: "The Dumb Virgin: Or the Force of Imagination." As the story goes, according to the "Physicians being consulted," it is the maternal imagination that is now in question and identified as the root of all evil.

Elsewhere in a contemporary moral treatise, fancy is also the subject of discussion. Published in 1711, four years after the union of the kingdoms of England and Scotland, Characteristics of Men, Manners, Opinions, Times, drafted by Anthony Ashley Cooper, Behn's contemporary, aims at cultivating an ideal eighteenth-century gentleman, and ranges over a variety of topics such as ethics, aesthetics, religion, the arts, history and literature. For the purpose of becoming "a Virtuoso (so far as befits a Gentleman)," and "a Man of Virtue and good Sense" (171), Shaftesbury inculcates, in "Soliloquy: or Advice to an Author," that British men "controul" their "Fancy" and "exercise" their "Reason in moral Subjects" (160). To fashion their "Justness of Taste" (182), Shaftesbury draws up a binary context of the self and the other, to protect the British, masculine self from "the Assault of FANCY," "against the Attacks which are rais'd on the side of corrupt Interest and a wrong Self," and specifically against "the whole fantastick Tribe of wanton, gay, and fond Desires" of women and effeminate men (161-162). Here rather than substantiate his thesis and mold a particular modal of "a Virtuoso" or "a Man of Virtue and good sense," he rushes headlong into enumerating and exemplifying the antitheses such as "Wonders of the Terra Incognita," "Turkish History," "ARIOSTO," "Romance," and "Novel" (177), censuring and castigating them as both "corrupt" and "wrong", and arbitrarily associating them with femininity and "Effeminacy" (175). 
As Shaftesbury thrashes out, women and effeminate men, craving for and falling prey to "Wonders of the Terra Incognita," are "more stuff'd with Bombast, ill Fancy, and wry Thought, than fill'd with solid Sense, and just Imagination" (176). In analogy, the Senator's wife in "The Dumb Virgin," for lack of "solid Sense" and "just Imagination," yearns so much for a visit to a remote, exotic island in the Adriatic Sea, to the extent that even the Senator himself could not hold, as Shaftesbury would put it, her unjust fancy, "under some kind of Discipline and Management" (166). As if synchronized, Behn's fiction and Shaftesbury's treatise invariably bring the question of fancy into focus and enter into a dialectical dialogue. While Shaftesbury brands and blasts women's and effeminate men's "ill Fancy" as "monstrous" (179), and "defective" (182), Behn, on top of that, constructs and visualizes a double defective femininity, as flawed imagination of the mother gives birth to a second generation of physically-flawed womanhood. ${ }^{4}$

\section{Constructing a Double Defective Femininity}

In "Soliloquy," Shaftesbury singles out women and effeminate men as his moral antitheses, slighting and slandering their "high imagination, florid Desires, and specious Sentiment" (186), which are subject to "Heterodoxy and Errour" (184), and thus censured as "Madness and Loss of Reason" (166) and "perverse Humanity" (183). Failing to be the "Controuler and Corrector" (166) of his wife's "Loss of Reason" and "perverse Humanity," Rinaldo "yielded to her desires," as "his love not permitting him the least shew of command" (421). As it turns out, Rinaldo's connivance with his wife's "defective" fancy, eventually "conspiring it own destruction" (421), is harshly punished and takes severe consequences for the unjust maternal imagination, as it is the direct antithesis to Shaftesbury's advocacy of the "Justness of Taste."

Taste, according to Shaftesbury, ought to be home-grown and "natural" (182), and more important, of "the honest and moral kind" (161), rather than the "monstrous Zeal" and "superstitious Passion" (179) for the unfamiliar and foreign, as exemplified by the Senator's wife's desire for the exotic island in the Adriatic Sea. While Shaftesbury bluntly blames the "Zeal" and "Passion" as "Deformity" (173), Behn enduringly exercises her pen and

\footnotetext{
${ }^{4}$ I notice that Jenny Morris, in her essay "Gender and Disability," points out the gendered character of disability in twentieth-century discursive practices and proposes a similar term: "double disadvantage" (85), in that the voice and experience of disabled women are replaced and represented by those of disabled men. However the terms: double defective femininity, and later double deformity, which I use in the present essay, though also gendered, define a fictional inheritance pattern in Behn's narratives, in which the heroines' disabilities are inherited and passed on from mother's imagination, which, in the novella as well as Shaftesbury's misogynist instruction, is considered "defective."
} 
weaves two tragic tales of double deformity. In "The Unfortunate Bride," Behn's female narrator in the story pairs femininity with disability by making Celesia, a gender and racial other, visually handicapped. Correspondingly, the wealthy Venetian senator's wife, in "The Dumb Virgin," gives birth to two disabled girl babies: the elder, Belvideera, is physically disfigured, while the younger, Maria, dumb. The first-person narrator attributes Belvideera's crippling to "the Frights and dismal Apprehensions of the Mother, at her being taken by the Pyrates," while Maria inherits muteness from "the Silence and Melancholy of the Mother" (424), who dies in giving birth to this second, speechless girl.

Although the cause of Celesia's visual impairment is hidden from view, those of Belvideera's and Maria's disabilities are explicitly explicated. If we take them at their face value, be it crippling of the body or disability of speech, their handicaps are ascribed to either the mother's "Frights and dismal Apprehensions" of nearly being taken captive and enslaved by the pirates, or her subsequent "Silence and Melancholy" for the loss of her baby boy. If we take a look at the bigger picture and the root cause of this series of mishaps and misfortunes would present to the view: it is the "desires" or "ill Fancy" of the mother, Senator Rinaldo's wife, for "an Island in the Adriatick Sea" (421), that becomes the target of criticism.

To be more specific, as indicated by the subtitle, "the Force of Imagination," what is at stake here is the power of maternal imagination, which is deemed dangerously destructive, or in Behn's word, "treacherous" (421). In fact, the prenatal influence of the expectant mother's imagination is by no means a contemporary idea. ${ }^{5}$ Dennis Todd, in Imagining Monsters: Miscreations of the Self in Eighteenth-Century England, explains why the belief in the maternal imagination prevailed in the eighteenth century:

The attribution of monstrosities to God or the devil had become less convincing as European thought had grown more secularized. Many of the other explanations were based on Aristotelian and Galenic embryological assumptions, and, as these increasingly became discredited, such causes fell out of favor. (48)

According to Todd's research, the power of maternal imagination gradually became the explanation of first resort, partly because Catholic and Protestant Europe gave way to the advent of new scientific and technological culture, and partly because Aristotelian and Galenic biological

\footnotetext{
${ }^{5}$ In "The Dumb Virgin," conventionalizing and stereotyping the image of femininity as "the treachery of the watry element," which solely bears the blame for the "destruction" (421) of Rinaldo's family, sounds too familiar, and reenacts once again the time-honored scenario of the legendary downfall of Adam and Eve in the Book of Genesis.
} 
anatomy about sexual difference ceased to make much impact at the end of seventeenth century. ${ }^{6}$ The belief in the prenatal influence of the mother's fancy was so prevalent and popular that by the early eighteenth century, as Todd argues: "It had overshadowed all other explanations of the causes of monstrous birth, and it was turned almost automatically to account for a wide variety of anomalies and malformations (47).",

As Behn's narrator presents in "The Dumb Virgin," what hangs in the air in the tragic romance is the mother's unbridled and ruinous "Force of Imagination" for an idyllic island in the Adriatic Sea, which eventually claims Senate Rinaldo's life and "treasure" (421). In Monstrous Imagination, MarieHélène Huet fleshes out this motif, which sheds more light on Belvideera's and Maria's disabilities in relation to the maternal imagination. On top of that, Huet's argument further delineates a delicate nuance, differentiating the heroines' physical and verbal impairments from their elder brother's birthmark. Though Huet generalizes that the maternal imagination "was primarily defined and understood in terms of imitation and resemblances" (9), "the power of imagination" as "invested in the very force of desire" (17), would sometimes simply leave behind it a "mark of a cherished and desired object" (16), which could be as innocuous as a blemish on the skin. Accordingly, the mother's fright and silence could lead to her daughters' disfigured limbs and muteness, whereas her excessive passion for a visit to an Adriatic island leaves no more than a slight trace of scar on the elder brother's neck.

In comparison with the brother's birthmark, his younger sisters' disabilities of contorted limbs and speechlessness not only enact the "imitation and resemblances" of the "Mother's violent imagination" (73), but their defective configurations of the mother's fear and silence also tap the gendered and sexualized vein of the romantic tragedy, on which Nussbaum comments cuttingly that the defective maternal imagination replicates a "secondary category of flawed femininity in the second generation" (28). In other words, "The Dumb Virgin" presents a double defective femininity, as the mother of defective imagination gives birth to two physically defective daughters.

\footnotetext{
${ }^{6}$ Thomas Laqueur, in chapter two of Making Sex, argues that "the boundaries between male and female are of degree and not of kind" (25), by first relating how Aristotle and Galen "constitute the one-sex model" (32) and then explaining "the longevity of the one-sex model" (62) over millennia, from classical antiquity to the end of seventeenth century.

${ }^{7}$ But in the early 1700 s, James Blondel was irritated by the hoax of Mary Toft, rumored to have given birth to seventeenth rabbits. Blondel disapproved that there used to be many theories on monstrosity. But now the mother's imagination "has been the constant Doctrine without any considerable interruption, till within these Hundred and Fifty years" (12). His disapproval could be referenced to substantiate the impact of the belief in the maternal imagination as the cause of monstrosity.
} 


\section{Monstrous Gender in Alliance With Monstrous Race}

Near the end of "Soliloquy," Shaftesbury warns the impressionable women and effeminate men against "Heathens, and Infidels... against their neighbouring Nations, of a false Religion, and Worship" (183). For the eighteenth-century English audience and readers, perhaps, Othello, Moorish and pagan, fits perfectly in this Shaftesburian stereotype of race, and best reifies the very concept of racialized and heathenized monstrousness in the English imagination, which threatens to undermine the English nation of "devout Christians" (183). Shaftesbury particularly warns contemporary women against this "Moorish Hero, full fraight with Prodigy: a wondrous Story-Teller." He fears that the impressionable English women, allegorized as "A thousand DESDEMONA'S" (179), would find it difficult to resist but succumb to "the miraculous Moor," who "cou'd relate the most monstrous Adventures, and satisfy the wondring Appetite with the most wondrous Tales" (178). ${ }^{8}$

Indeed, Shakespeare's Othello, a paragon of "Heathens, and Infidels," does win the heart of the heroine by feeding her "wondring Appetite" with his adventurous and thrilling tales, as Desdemona would "come again, and with a greedy ear/Devour up my [Othello's] discourse" (1.3.149-150). ${ }^{9}$ Shaftesbury would frown upon the young heroine's weakness for Othello's "monstrous Adventures" and "wondrous Tales," as he would sound the alarm that these exotic tales would monstrocize Barbantio's daughter and eventually the heroine would, as Nussbaum puts it, "come to embody the very monstrosity" herself, as listening to Othello's monstrous stories in travel and war would turn her into a monster (4). Shaftesbury would also agree that it is the alliance between monstrous storyteller and monstrous storylistener

\footnotetext{
${ }^{8}$ Nussbaum also interprets that this "irresistably" "contagious" craving for the exotic and "monstrous tales" will transform "women and effeminate men" into "that very monstrosity themselves," as indulging in "travel narratives threatens to make monsters of them all" (4). In other words, men and women, passionate for exotic and fantastic tales, have themselves come to incarnate the monstrousness of the "travel narratives," the impact of which will fashion them into "monsters." (6)

${ }^{9}$ Desdemona is so enthralled with Othello's tales that she, in defiance of her father, ventures to elope with Othello. In fact, Desdemona's father, Senator Barbantio, charges Othello with binding his daughter "in chains of magic" and accuses him of casting a spell on Desdemona: "She is abused, stol'n from me, and corrupted/By spells and medicines" (1.3.60-61). To defend against Barbantio's accusation, Othello justifies himself : "Her father loved me, / Still questioned me the story of my life / From year to year, the battles, sieges, fortune / That I have passed" (1.3.127130). In light of it, Geraldo U. de Sousa aptly remarks, "Obviously on some level, he [Barbantio], like his daughter, was fascinated with Othello's narrative" (119). Therefore, as Senator Rinaldo in The Dumb Virgin could not hold his wife "under some kind of Discipline and Management," so could Desdemona's father, Senator Barbantio do nothing to stop his daughter's elopement and interracial marriage.
} 
that opens the pandora's box of monstrocities in Othello. Elsewhere Natasha Distiller also voices a similar view: "Othello is a play about the vulnerabilities of difference and how difference is constructed," as "Othello's vulnerability to lago" and "Desdemona's vulnerability to Othello" literally precipitate the tragic denouement (339-340). Whether modeled upon "monstrousness" or "vulnerability," the gender and racial others throw the play into complete turmoil, and unleashes terror and mayhem at the end of the tragedy. Like Othello, Behn's "The Dumb Virgin" and "The Unfortunate Bride" also ring down their curtains red-handedly. But the homicidal wind-ups of the feminocentric romances are not simply attributable to the protagonists' "vulnerabilities," as Distiller reasons. Rather, Behn's narratives, more delicately and dramatically narrated than Shaftesbury's didactic "Soliloquy," portray how ruinous and subversive an effect the alliance of the two subcategories of Otherness would heighten.

In "The Dumb Virgin," Belvideera and Maria's elder brother, Dangerfield, who is believed to have drowned during the pirate attack, is challenged to a duel on his first visit to the Senator's house. While fighting with two rivals for Maria, Dangerfield drops his wig and reveals his birthmark, by which the wounded and dying Rinaldo recognizes his long-lost son, and over which Maria, unwittingly falling in love with her biological brother, is so distraught with grief to the point that she suddenly raps out her first and last words: "Oh! Incest, Incest" (444), before committing suicide with her lover's/ brother's sword. In "The Unfortunate Bride," on the other hand, on account of Moorea's conspiracy, Frankwit fails to marry Belvira, and, in a frenzied fit of jealousy, kills his rival and best friend Wildvill, who, before he dies, accidently inflicts a mortal wound on his beloved and newlywed, Belvira.

Both romantic love stories conclude with a series of violent deaths of either father, or son, or daughter, or newlywed, or friend, of whom the deaths are scandalously and memorably branded either by incest, or suicide, or patricide, or amicicide, or uxoricide. The havoc on such a monstrous scale could not have been wreaked alone by either of the two sub-categories of the humans. In fact, the plot in "The Dumb Virgin" only takes a sharp decline in Dangerfield's dying moment. It is the moment when the wounded Dangerfield "accidentally dropt his Wig in the Engagement" that "the Mark of a bloody Dagger" (443) links this defect-ridden household with the aborted Turkish pirate attack, which is remindful of "the loss of her [the mother's] liberty," and "the danger of her [the mother's] honour" (422), and most notoriously, points to the monstrous effect of maternal imagination. That is, not until the sudden revelation of Dangerfield's "Mark of a bloody Dagger" does the mother's "Fancy" for an Adriatic island brings once more to light. Though Dangerfield, like Othello, is renowned for his "brave Performance against the Turks" (439), he was found, in his babyhood, "ty'd to two Planks" 
and later brought up by "a Turky Merchant" (443), "the common Foe of Christianity" (429). But now, this Turkish-turbaned young suitor, the adopted child of a rich racial/religious other, comes back to Venice in hopes of finding his parents, but only to commit incest and patricide, and partake of the death of his sister Maria.

The alliance of gender and race proves more monstrous in "The Unfortunate Bride," as Frankwit and Belvira's romance is maliciously disrupted by "a Blackamoor Lady," Moorea, a sexualized/racialized/heathenized she-monster/"Devil." After the shedevil sends the false news of Frankwit's death, the story starts to take a drastic and dramatic downturn. Belvira - "fully convinc'd of Frankwit's death," and "urg'd by the fury and impatience of her new ardent Lover" (412) - marries her fiancé's best friend, Wildvill, which soon afterwards leads to a duel between the two best friends, Frankwit and Wildvill, the latter of whom dies in the duel and accidentally murders his newlywed wife, Belvira. Though the ill-fated bride, at her last gasp, still instructs Celesia to marry Frankwit, amid the melee and misery of bloodshed and death, can the promise of marriage, in the wake of amicicide and uxoricide, flash any faint hope of an anticlimax? On top of that, despite recovering her sight and inheriting Belvira's fortune, will Celesia, "an Heiress, the only Child of a rich Turkey Merchant" (405), another disconcerting conglomeration of gender, race, and disability, stand any chance of faring well with Frankwit in the aftermath? In brief, if Philip Kolin takes Othello as "a cultural seismograph, measuring the extent and force of gender, racial, or class upheavals" (1), then readers may have just witnessed the seismic waves of gender and race in "The Dumb Virgin" and "The Unfortunate Bride," travel up-and-down and side-to-side through the two textual terrains, rocking the narrative structures by inflicting casualties and displacing families.

\section{5. (RE)DRAWING THE BOUNDARY OF THE HUMANS}

Laura Brown expends great efforts in assessing the contemporary critics of colonial and postcolonial literature in Ends of Empire: Women and Ideology in Early Eighteenth-Century English Literature. ${ }^{10}$ At the end of her

\footnotetext{
${ }^{10}$ Brown's study runs the gamut of the contemporary critics such as Edward Said, Frantz Fanon, Abdul JanMohamed, Tzvetan Todorov and Homi K. Bhabha. From their critiques, Brown finds that "the dominant discourse of colonialism produces this difference [race] when it attempts to represent the native" (30), by modeling a dualism of binary opposition, either between imperialist and native, or between colonizer and colonized. Among them, Bhabha acutely argues that this colonial representation of the other is constructed to meet the "narcissistic demand of colonial authority" (88), on which Stephen Greenblatt chimes in unison that the racial other is concocted "by the colonial power in its own interest" (24). In view of the "narcissistic" and self-interested nature of colonial discourse, Brown interprets perceptively and drives home that the discourse intends "to minimize or eliminate the notion of an active or
} 
book, Brown concludes that gender and race "are not independent variables within a hegemonic edifice, but interdependent variables with mutualities of their own" (199). In spite of stressing their interdependency and "mutualities," she nevertheless draws a geographical line between gender and race elsewhere and prioritizes the former over the latter. As Brown makes her case,

This perspective places gender before race, because gender represents a category of difference constituted primarily within the geographical purview of the dominant culture, whereas the understanding of race in this period... remains mainly extrinsic, geographically foreign, a category of difference defined as an external object. (136-137)

This critical notion sums up Shaftesbury's concept of gender and ethical others in his moral treatise, a typical "hegemonic edifice" as such. Indeed, even though Shaftesbury's ideal cultural paradigm for "the Faithful" and "devout Christians" (183) makes no room for either susceptible women, or effeminate men, or racial others, he nevertheless demarcates a frontier line between women and effeminate men, who are incorporated "within the geographical purview of the dominant culture," and racial others, such as Othello, "Mahometans" and "Pagans," who fall outside of this European ethnic and cultural dominion. Despite sharing their mutual "vulnerability" and "monstrousness," as set out respectively by Distiller and Shaftesbury, this metaphysical barrier geographically separates gender from race into two "independent," geographical correlatives of intrinsicity vs extrinsicity, or internality vs externality.

Regardless of the shared "mutualities" between these two excluded sub-groups of Otherness, the geo-cultural and -political parameter has dualistically segregated gender from race into Europe inside and nonEurope outside. And this layout structurally falls in with James M. Blaut's "Inside-Outside model": ${ }^{11}$ "the mythology of Europe's permanent geographical superiority and priority" (13), ${ }^{12}$ in The Colonizer's Model of the

autonomous resistance, and sometimes of any opposition at all" (32).

${ }^{11}$ Shaftesbury's cultural configuration fits right in Blaut's "Inside-Outside model," in which race "remains extrinsic" and is "defined as an external object." For the purpose of cultivating "a right TASTE in Life and Manners" (174), Shaftesbury dichotomizes people, within the "Europe inside" between the class of men of "Virtue and good Sense," and two sub-classes of difference: "silly Women" (179) and effeminate men. The former, of the Christian, "honest and moral kind" (161), "hold[s] his Fancys under some kind of Discipline and Management" (167), while the latter, "monstrous" and deformed, fall prey to "Barbarian Customs, Savage Manners, Indian Wars, and Wonders of the Terra Incognita" (177)

${ }^{12}$ The myth of this Eurocentric model, according to Blaut, is based upon a general assumption, which follows the watershed of the year 1492. Before Columbus's voyage of discovery in 1492, 
World. Blaut analyzes and illustrates this Eurocentric myth from biological, environmental, epistemological, technological and social perspectives. In terms of race, two notions on human categorization are worthy of being noted:

Non-Europeans who were classified as members of the white (socalled) race were nonetheless believed to be inferior because they belonged to inferior subraces. Sometimes Europeans themselves were divided into superior and inferior subraces. (61)

As Blaut explains, though "Semitic peoples," such as Phoenicians, Hebrews, and Arabs, "belong to the white race," they are considered "inferior," in comparison with the Europeans, who are "the really superior subrace of whites." In turn, the Europeans themselves are further hierarchized into superior northern Europeans, and "inferior" southern and eastern "subraces of whites" (63).

What these two racist and elitist assumptions have in common is that they are both geographically- and hierarchically-based. In light of this, it would be interesting to compare the aforementioned three discourses and point out their coordinate point, where these three discrete discursive lines intersect. On this two dimensional coordinate plane of gender and race, Blaut's diachronic survey is masculine-centered and even makes no mention of the gender issue whatsoever, despite his extensive survey of geography, politics and history, while, regardless of its "revisionist undertaking" (10), Brown's synchronic study, together with Shaftesbury's moral construct, could not but delimit a dualistic deadlock of "misogyny" and "racism" (199).

By contrast to the above dualistic and oppositional visions, Behn's tragic novellas intermingle the issues of "misogyny" and "racism," and provide an anti-dualistic and dialectical insight through the intricate interplay of fancy, gender and race. In spite of re-enacting the conventional misogynist and racist motif of fancy in these twin narratives of female defect, it is fancy that negotiates the insoluble borderline inbetween gender and race. Against this traditional misogynist and racist backdrop, fancy liaises with gender and race in terms of their shared elements of defectiveness and monstrousness. Be it the maternal imagination in "The Dumb Virgin," or erotic desire for or of the shedevil in "The Unfortunate Bride," fancy in Behn's stories of defect invariably melts gender and race into a defective and monstrous alliance, which intertexualizes the discursively insulated terrains of gender and race, and thus interprelates the indelible "geographical

the evolution of Europe depended on its "internal forces, not because of the inflowing of wealth and innovations from non-Europe." After the beginning of the Age of Exploration in 1492, the world became a place that witnessed "an outflowing of modernization from Europe" (59). 
purivew" and racial hierarchy, as defined by others. In other words, Behn's representation of fancy, gender and race, through the first-person accounts, dissolves the geographical dichotomy of internality and externality, demystifies the mythical hierarchy of superiority and inferiority, and thus slackens the fixed categories of gender and race, making them less identifiable and more difficult to locate.

\section{BeHn's Deployment of a Female NARRATOR: A BREAKTHROUGH}

Witnessing first-hand each of the two disastrous denouements, Behn's first-person narrator and character, appears either speechless, or helpless. In "The Dumb Virgin," the narrator/character, viewing a series of violent deaths of father, daughter and son, is "struck dumb by the Horror of such woeful Objects" and "cou'd make no Answer" (444), while in "The Unfortunate Bride," the female narrator/character fails to make any impact on averting the tragic ending, despite claiming herself as a "particularly intimate Acquaintance" of the heroine Belvira" and having successfully retrieved the intercepted letters (413). Arriving too late with the regained "bundle of Papers" to prevent her bosom friend from marrying Wildvill, the narrator laments, "What Tongue, what Pen can express the mournful Sorrow of this Scene" (413), as she looks speechlessly and helplessly on the sad reunion of the two lovers.

Citing Behn's deployment of a first-person female narrator, Ros Ballaster considers that "Behn's narrative strategies, whereby woman is represented as simultaneously subject (the female writer) and subjected (the female character) within the social order, are a register of confusion, as well as an attempt to resolve it" (189), and she concludes that the two feminocentric novellas present "a complex interplay of these two poles of vision and writing" (202). Whether Behn's simultaneous representation of woman as "the female writer" and "the female character" would create textual "confusion" will be subject to further discussion. As the focal point of this line of argument, this paper pursues nothing other than the placement of first-person female narrator and how she as "subject" positions herself with the "subjected": namely, gender and racial others in the two short fictions.

In this regard, both Behn and Defoe are considered the pioneers of the early modern novel, and both are committed to authenticating the account of their narratives by deploying a first-person female narrator. However their narratives present two very different views on fictional writing. In Defoe's fiction, the editor from time to time comes to the fore and exercises censorship in disciplining the female discourse, while in Behn's, her narrator all too often either rushes in places where angels fear to tread, or excuses herself for her intellectual incompetence. It would be timely to note that, in the preface to Moll Flanders, the editor has the start, 
He original of this Story is put into new Words, and the Stile of the famous Lady we here speak of is a little alter'd, particularly she is made to tell her own Tale in modester Words than she told it at first...(1)

As readers can see, Moll Flanders' self-revelation is toned down, "a little alter'd" and "put into new Words" for the purpose of making her story "modester," as addressed by the male editor. In other words, the selfaccount of the first-person female narrator is subject to review by the male censor, or "The Pen," to "put it into a Dress fit to be seen, and to make it speak Language fit to be read" (1).

At one with Shaftesbury's propagation for the "Justness of Taste," the male supervisor assumes himself as the moral arbiter, and this malecentered norm examines the female narrator's narrative, and amends, in Moll's recount, the so-called "leud ideas" and "immodest Turns," which are deemed objectionable on moral terms (1-2). As a result, "some of the vicious part" is either "quite left out" or "very much shortn'd," to the end that "what is left 'tis hop'd will not offend the chastest Reader, or the modestest Hearer" (2). By contrast, Behn's female narrator picks up what Defoe and Shaftesbury would either reprove or censure, be it the "leud ideas" and "immodest Turns" of either incest, or suicide, or patricide, or amicicide, or uxoricide, or the maternal imagination, or the monstrousness of gender and ethical others. Instead of disciplining her "Tongue" and "Pen," like her male counterparts would do, she would rather expose her incompetence by either being "struck dumb" or helpless, than change the course of her stories.

For this reason, it is worth noticing that elsewhere Behn effaces herself as a second-rate prose writer in her dedication to another fiction "The Fair Jilt," by playing down her talent for poetry, the higher designation of intellectual prowess. In an act of insinuating herself into the favor of peer male critics, she hides her light for poetic creation in the bushel and lowers her tone: "Poetry (my Talent) has so greatly the Ascendant over me, that all I write must pass for Fiction" (70). Driving home Behn's self-effacement by retiring into the shell of fiction writing, Ellen Pollak's argument, in The Poetics of Sexual Myth: Gender and Ideology in the Verse of Swift and Pope, accentuates the pervasive domination of patriarchy in all aspects of life during this period of time:

As patriarchal notions of divine-right monarchy were rejected by political theorists... as empiricist philosophy increasingly designated the human subject as the locus both of psychic and of referential truth, new terms in keeping with these individualist traditions gradually evolved to accommodate the ongoing subordination of women to men 
in social, political, economic, intellectual and domestic life. Fuller and more complex strategies begin to emerge for resolving the increasing autonomy of the masculine subject... and the denial of either desire or autonomy in women. (2)

To circumvent intellectual censorship of male "psychic" and "referential truth," Behn is obliged to give in her poetic power, and diminish herself as a second-fiddle teller of tales, rather than publicly pit her wits against male peers and excel herself as a preeminent poet. However, this simulated surrender to patriarchal authority and

self-abasement for a lesser, secondary narrative space in fact not only provides Behn with a protective shield against prevalent masculine surveillance, but also allows her to freely express her "desire" and exert her "autonomy" between the lines, in the face of "the increasing autonomy of the masculine subject" and "ongoing subordination of women to men."

Correspondingly, rather than be seemingly incompetent as the firstperson narrator/character might look at first sight in "The Dumb Virgin" and "The Unfortunate Bride," Behn's narrator is well versed in the arts of taking one step back for two steps forward as both a "subject" and "subjected." In fact, rather than trigger any textual "confusion," as cautioned by Ballaster, Behn's deployment of a double as both "a female writer" and "a female character" has strategically aligned her writer self with the subcategories of gender and racial others. By doing "Justice" $(423,444)$ to her characters, regardless of their gender and race, her female pen has at the same time done herself "Justice," justified her literary imagination, and thus

established herself as a female fiction-maker. More noticeably, the expression of her "desire" and assertion of her "autonomy," through the realization and representation of the "category of difference," has quietly but successfully stamped her name on the misogynistic camp of malemonopolized literary discourse.

\section{CONCLUSION}

Sandra Young, reviewing the Renaissance drama and performance, reflects that the

Renaissance stage offers an opportunity for modern day critics to explore the early modern imaginary within which notions of Englishness are constructed, a construction that relies in large measure on the conjuring of identifications against which Englishness might be asserted. (22)

It is on this line of thought that Shaftesbury models his ideal 
eighteenth-century "Virtuoso" on four "identifications"--"Moorish Fancy" (179), "Mahometans" and "Pagans" (181), "Woman-kind" (178) and "Effeminacy" (162)--against whom and which Shaftesbury "asserted" his ideal "Man of Virtue and good Sense" (171). ${ }^{13}$

As it turns out, Behn's feminocentric stories stand at odds with this patriarchal frame of mind. As Jacqueline Pearson concludes in chorus in "Slave princes and lady monsters: gender and ethnic difference in the work of Aphra Behn," "Behn's texts" undermine "the very foundations of the binary habits of thought through which a white aristocratic patriarchal culture excludes its Others and maintains itself in power" (231). Therefore, in contrast to Shaftesbury, Behn's maternal imagination, on one hand, exposes the dualistic construct of her male counterpart's "white aristocratic patriarchal" reasoning, whereas, on the other hand, via the female narrator's "self-contradictory position"14 and her alliance with the "Others," Behn dialectically transcends this conventional confines of socio-sexual hierarchy and gender-racial dichotomy, and masterfully achieves a breakthrough amid the pervasive patriarchal discursive dominance.

\title{
BIBLIOGRAPHY
}

Anon., Female Rights Vindicated; Or the Equality of the Sexes Morally and Physically Proved by a Lady. London: G. Burnet, 1758.

Bhabha, Homi K., The Location of Culture. London: Routledge, 1994.

Ballaster, Ros, "'Pretences of State': Aphra Behn and the Female Plot." En: Rereading Aphra Behn: History, Theory, and Criticism. Charlottesville:

\footnotetext{
${ }^{13}$ It is interesting to note that Linda Colley, in her survey of the evolution of Britishness, also marks this mental mechanism en route to establishing the national identity in the early eighteenth-century. As Colley mentions in Britons: Forging the Nation, 1707-1837, after the Acts of Union took effect in 1707, many English considered their Scottish counterparts "poor and pushy reations," and they "bitterly disapproved of 'English' and 'England' giving way to 'British' and 'Great Britain."' After all, it is said that "Scotland... is certainly the sink of the earth" (13).

${ }_{14}$ Jacqueline Pearson's study on "Oroonoko" is in concert with this essay, as she proposes perceptively,
}

\begin{abstract}
In Oroonoko Behn implicitly identifies white women with Black slaves, and her own white female narrator with the Black slave protagonist: both are in an anomalous and self-contradictory position with regard to status and authority, he as a prince but also a slave, she as a member of a ruling elite but also a woman. (220)
\end{abstract}

Correspondingly, Behn's deployment of a double of narrator and character, or in Ballaster's words, "subject" and "subjected," in "The Dumb Virgin" and "The Unfortunate Bride," also intends to "destabilize" and "unsettle" (231) the "inherited stereotypes of racial, as of gender, hierarchies" (220), as Pearson contends. But more than that, it also enables the narrator or the "subject" to make out her case to do her maternal imagination justice. 
UP of Virginia, 1993, pp. 187-211.

Behn, Aphra. "The Dumb Virgin; Or the Force of Imagination." En: The Works of Aphra Behn, vol. 5. New York: Phaeton P., 1967, pp. 415444.

—, "The Fair Jilt." En: The Works of Aphra Behn, vol. 5. New York: Phaeton P., 1967, pp. 67-124.

—, "The Unfortunate Bride; Or the Blind Lady a Beauty." En: The Works of Aphra Behn, vol. 5. New York: Phaeton P., 1967, pp. 399-414.

Blaut, James M., The Colonizer's Model of the World: Geographical Diffusionism and Eurocentric History. New York: Guilford P., 1993.

Brown, Laura, Ends of Empire: Women and Ideology in Early EighteenthCentury English Literature. Ithaca: Cornell UP, 1993.

Colley, Linda, Britons: Forging the Nation, 1707-1837. New Haven: Yale UP, 1992.

Cooper, Anthony Ashley, Third Earl of Shaftsbury, Characteristics of Men, Manners, Opinions, Times. Oxford: Oxford UP, 1999.

Defoe, Daniel, Moll Flanders: The Fortunes and Misfortunes of the Famous Moll Flanders. Oxford: Oxford UP, 1998.

De Sousa, Geraldo U., Shakespeare's Cross-Cultural Encounters. Hampshire: Palgrave, 2002.

Distiller, Natasha, "Authentic Protest, Authentic Shakespeare, Authentic Africans: Performing Othello in South Africa. En: Comparative Drama 46, 3, 2012, pp. 339-54.

Goreau, Angeline, Reconstructing Aphra: A Social Biography of Aphra Behn. New York: Dial P., 1980.

Greenblatt, Stephen, Political Shakespeare: New Essays in Cultural Materialism. Ithaca: Cornell UP, 1985.

Hobby, Elaine, Virtue of Necessity: English Women's Writing, 1649-1688. Ann Arbor: Univ. of Michigan P, 1988.

Huet, Marie-Hélène, Monstrous Imagination. Cambridge, MA: Harvard UP, 1993.

Hutner, Heidi, Rereading Aphra Behn: History, Theory, and Criticism. Charlottesville: UP of Virginia, 1993.

Kolin, Philip, "Blackness Made Visible: A Survey of Othello in Criticism, on Stage, and on Screen." En: Othello: New Critical Essays. New York: Routledge, 2002.

Laqueur, Thomas, Making Sex: Body and Gender from the Greeks to Freud. Cambridge: Harvard UP, 1990.

Morris, Jenny, "Gender and Disability." En: Disabling Barriers--Enabling Environments. London: Sage, 1993.

Nussbaum, Felicity, The Limits of the Human: Fictions of Anomaly, Race, and Gender in the Long Eighteenth Century. Cambridge: Cambridge 
UP, 2003.

Pearson, Jacqueline, "Slave Princes and Lady Monsters: Gender and Ethnic Difference in the Work of Aphra Behn." En: Aphra Behn Studies. Cambridge: Cambridge UP, 1996.

Perry, Ruth, Women, Letters, and the Novel. New York: AMS P, 1980.

Pollak, Ellen, The Poetics of Sexual Myth: Gender and Ideology in the Verse of Swift and Pope. Chicago: U of Chicago P, 1985.

Pope, Alexander, The Poems of Alexander Pope. London: Metheun, 1963.

Shakespeare, William, Shakespeare: The Complete Works. London: CRW Publishing Limited, 2007.

Smith, Hilda Lee, Reason's Disciples: Seventeenth-Century English Feminists. Urbana: U of Illinois $\mathrm{P}, 1982$.

Spenser, Jane, The Rise of Woman Novelist: From Aphra Behn to Jane Austen. Oxford: Basil Blackwell, 1986.

Todd, Dennis, Imagining Monsters: Miscreations of the Self in EighteenthCentury England. Chicago: U of Chicago P, 1995.

Todd, Janet, Aphra Behn Studies. Cambridge: U of Cambridge P, 1996.

Young, Sandra, "Imagining Alterity and Belonging on the English Stage in an Age Expansion: A reading of Othello." En: Shakespeare in Southern Africa: Journal of the Shakespeare Society of Southern Africa 23, 2011, pp. 21-29. 